\title{
Factors Affecting the Market Price of Fish in the Northern Part of Surigao Del Sur, Philippines
}

\author{
Alapan, Maribeth P., Arpilleda, Errah Layza I., Altizo, Kemberly Jane R., Frias, Gerlyn \\ Keene R., \& Ravelo, Jocel D. \\ Surigao Del Sur State University, Cantilan Campus, Cantilan Surigao Del Sur,
} Philippines

Tel: 212-5391Ｅ-mail: ocuartero@yahoo.com

\section{Cuartero, Odinah L. (Corresponding author)}

Science Department, Surigao Del Sur State University, Cantilan Campus, Cantilan Surigao Del Sur, Philippines

Tel: 63-926-804-2192 E-mail: ocuartero@yahoo.com

Received: Sep. 29, 2016 Accepted: Oct. 5, 2016 Published: December 17, 2016

doi:10.5296/jee.v7i2.10469 URL: http://dx.doi.org/10.5296/jee.v7i2.10469

\begin{abstract}
The study focused on the factors affecting the market price of fish in northern part of Surigao del Sur, Philippines. The study also attempted to find the significant difference among the identified factors affecting the market price of fish. The respondents of the study were the fishermen, middlemen, fish vendors and consumers of the six (6) identified coastal barangays in northern Surigao Del Sur namely: Linintian, Magosilom, San Pedro, Consuelo, General Island and Ayoke. The researcher-made questionnaire was the tool used in the study. Mean and ANOVA (Analysis of Variance) were used to quantify and analyse the gathered data. Based on the findings of the study, among the five (5) identified factors affecting the market price of fish, the quality of fish, as a factor, was found to greatly affect the market price of fish while water pollution was considered as the lowest factor affecting the market price of fish. Furthermore, it was found that all the five identified (5) factors cited in the study had significant contributions on the formulation of the market price of fish in the northern part of Surigao Del Sur.
\end{abstract}

Keywords: Price demand, Market price, Price differentials, Quality of fish 


\section{Introduction}

The Philippines ranked among the major fish producing countries in the world with a total production of 3.1 million tons of fish and other aquatic animals HLPE (2014). One of the regions in the country with an island-dwelling population of more than hundreds of fishing areas is located in Mindanao, particularly in Surigao Del Sur, where fishing is the common livelihood. However, fisher folk themselves - apparently face a critical dilemma for a reason that several intervening factors affect and limit access to fishing. Eventually, consumers who are dependent on them are mainly affected by the price demand of fish being sold.

According to Namisi (2005), few of the major factors identified to influence the price demand of fish in the market include environmental change, quality of fish, water pollution, location and the price demand of key informants. Knowing the factors that affect the market value of fish can help the producer and consumers create and establish the buying and selling strategies. On the study of Savin, et.al, (2010), fish prices may vary considerably by different factors; however, the more educated producers and consumers are about the process, the better their chances to address the problems of both the fisherman and consumers and make a good profit.

In fish marketing, wholesale trade between fishermen and fish merchants or the sales of seafood are marketed in different categories. The live food fish trade is a global system that links fishing communities with markets (Green, et. al., 2004). In microeconomics, supply and demand is an economic model of price determination in a market. It concludes that in a competitive market, the unit price for a particular good or other trade item such as labor or liquid financial assets will vary until it settles at a point where the quantity demanded (at the current price) will equal the quantity supplied (at the current price) resulting in an economic equilibrium for price and quantity transacted (Peterson, 2007).

Commercial fisheries are impacted by many environmental factors. A bigger environmental impact occurs with dramatic climatic changes, such as El Niños (warm water events) and La Niñas (cold water events). Both El Niño and La Niña cycles affect water temperature and the availability of nutrients for fish. As a result, there is a change in fish distribution (where the fish are found) and abundance (the number of fish), and the change is different depending on the fish.

Yamashita (1996) claimed that there are a number of varying factors affecting the market price of fish. Few of these dealt on freshness and quality measurement, domestic price differentials, monopsony, storable and non-storable products, adequacy of statistics and production-retail price differentials. It is important, therefore, to close examine the formulation of the market price of fish based on the varying factors. The realities of fish and seafood production and the resulting threat to wild stocks of fish and seafood species will require careful management to assure both a sustainable supply of wild catch and sustainable growth in aquaculture to meet demand (Craig, J.F., 2014). These changes impact local commercial fishing operations when the events occur and often for several years after the events. The distribution of fish often changes right away. 
Without centralization, it is unclear whether the price response could have been as effective in allowing demand to match supply as buyers might have suspected gouging on the part of the sellers if prices were not easily comparable.

It can be difficult in some way to predict the prices of fish, because they constantly vary based on differing factors. In the province of Surigao Del Sur, the usual practice in buying and selling fish is done directly from the fishing boat to the consumers. This is similar to what local fishermen and farmers have done in several places whereby fish and agricultural products are directly sold from the harvest area to consumers (DA-BFAR, 2004). Although the Local Government Unit (LGU) of the area is aware of the upsetting trading, consumers repeatedly do the same practice despite the fact that some consumers complain and doubt how the system on market pricing of fish is done. In this context, fish selling and buying guide and regulation strategies are being compromised, leading to poor economic competition (USAID, 2013).

In view of this situation, the researchers conducted a survey regarding the factors affecting the market price of fish in the northern part of Surigao Del Sur. The result of the study served as basis for pricing recommendation strategy in buying and selling of fish in the northern area of Surigao Del Sur.

\subsection{Objectives}

The study focused on the factors affecting the market price of fish in the northern part of Surigao Del Sur. The study further aimed to assess which of the identified factors greatly affect the market price of fish, which factor has the least effect, and the significant difference among the factors affecting the market price of fish in the northern part of Surigao Del Sur.

\section{Methodology}

The study made use of the descriptive - survey method using researcher-made questionnaire as main instrument to gather data. The researcher-made questionnaire was composed of questions categorized into four (4), one for each of the intended respondents: fishermen, middlemen, fish vendor and consumers. Each question category contained competencies based on the Local Ordinance No.2-2008 Section 6 for Selling and Buying Strategies of Fish, which addresses the identified factors affecting the market price of fish. Informal interviews and observation were made to verify data and ascertain the validity of the respondents' answers.

The respondents of the study were the fishermen, middlemen, fish vendors and consumers of the six (6) identified coastal barangays in northern part of Surigao Del Sur, namely: Linintian, Magosilom, San Pedro, Consuelo, General Island and Ayoke. The respondents were chosen because they were the reliable and key informants who could answer and give important information with regards to the factors affecting the market price of fish. Stratified Random Sampling Technique was used to identify the respondents.

\subsection{Treatment of Data}

The data gathered were analyzed and interpreted using Mean and ANOVA or Analysis of 
Variance to quantify if there would be a significant difference among the identified factors affecting the market price of fish.

\section{Results and Discussion}

\subsection{Factors Affecting the Market Price of Fish}

The figure compares the factors affecting the market price of fish in the northern part of Surigao Del Sur. Among the factors affecting the market price of fish in the northern part of Surigao Del Sur, the indicator on the Quality of Fish has the highest mean value of 4.9, followed by Location (mean value $=4.75$ ); Weather Condition $($ mean value $=4.65$ ); Price Demand $($ mean value $=4.45)$ and Water Pollution $($ mean value $=4.15)$.

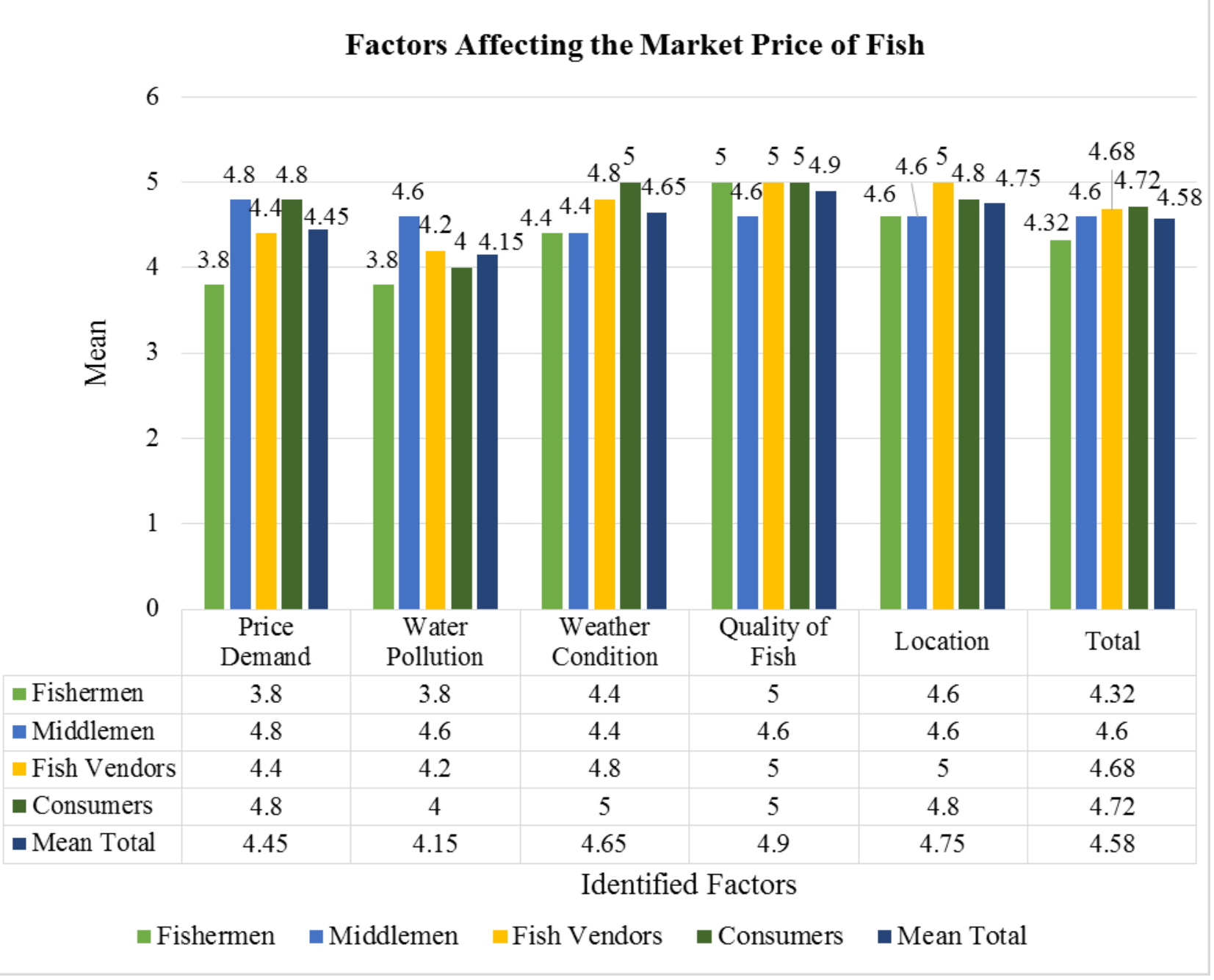

Figure 1. Mean of the identified factors affecting the market price of fish in northern part of Surigao Del Sur

From the four (4) respondents, fishermen, fish vendor and consumers equally responded that quality of fish significantly affects the price of fish. The factor, Quality of fish, was found to greatly affect the price of fish provides high demand in the market. Most of the consumers preferred to purchase high quality and fresh fish to ensure the health safety and satisfaction 
needs of their families are met. The location and weather conditions are two of the factors that also contribute on the market price of fish. Fish are less likely to come up during bad weather because they too are extremely sensitive to the weather changes. On the other hand, fishermen are reluctant to venture in far places with unpredictable weather condition for it creates a risky situation and uncertainty of catch. With that condition, fish vendors and consumers are the end receivers, which for them, location and weather conditions are two important factors to look into before going fishing. The result is further supported by the study of Graddy (2006). He cited that the quantity of fish brought to market is determined by many factors, but the weather is an important determinant of supply since strong winds and high waves make it difficult to catch fish. Quantities fall and prices rise when there are storms and quantities rise and prices fall in good weather. The idea of Graddy connects with the idea of Bruton, (1990) that weather and location are two of the factors that affect the market price of fish. According to Bruton,(1990), fish is perishable and if it is to be sold in good condition, it must be taken to the market within the shortest time period or it must be preserved. Since preservation adds costs, it was considered that traders should instantly sell their fish at the nearest market to avoid deterioration of quality, which would influence price of fish.

Price demand is the fourth factor which also has significant effects on the market price of fish. Since the fisherman, middleman and fish vendors have no fixed prices on the catch of fish, some of them adjust their prices depending on the factors they have experienced. The distribution process from fisherman, middleman and fish vendor most of the time is altered due to lack of adequacy on estimating the appropriate retail price. The result is supported by the study of Yamashita (1996) where he stated that several factors affecting the market price of fish is concerned on the practice of monopsony. According to his study, if the importer of a product is a monopolist, the price of imported goods should be lower than otherwise. In that instance, the competitiveness of the product in the world market should be taken into account. As stipulated in Municipality of Cantilan, Surigao Del Sur Ordinance no. 2-2008 Section 6, the prevailing shall be determined in time of emergency or calamity after certification from the Local Chief Executive.

From the five (5) identified factors, the Water Pollution is reflected to be the least factor affecting the market price of fish with a mean of 4.15. This means that the freshness and fish species have significant influence on the price of fish. The lowest factor affecting the market price of fish in the northern part of Surigao Del Sur is the water pollution because fishermen prefer to avoid areas where water is polluted; instead, they travel beyond to other location where the water is clean. Compared to clean water, where there are lots of fish that are of quality and different species, polluted water may have little number of fish which are unsafe and unhealthy to consume. The result agreed with the study of Israel (2004), that low income of fishermen can be attributed to declining fish catch due to poor access to clean water and environment which greatly affects the production of different fish species. The daily income of fishermen, middle person and fish vendors will be altered and will lead to significantly higher poverty incidence.

Results conveyed that the quality of fish as one of the factors affecting the market price of 
fish greatly affects to the price value of fish. Furthermore, it is cited to have a high demand among the expert informants and consumers.

\subsection{Difference among the five (5) factors affecting the market price of fish}

The table shows the computation of the analysis of variance of the data collected from the informants of the study. Since the computed value of $\mathrm{F}$ is 3.336 , which is greater than the critical value of 3.06 at $5 \%$ degree freedom, the null hypothesis is rejected.

Table 1. Two-way Analysis of Variance (ANOVA) on the different factors affecting the market price of fish in the northern part of Surigao Del Sur

\begin{tabular}{lccccc}
\hline \multicolumn{1}{c}{ Factors } & $\begin{array}{c}\text { Sum of } \\
\text { Squares }\end{array}$ & df & Mean square & F & Significant \\
\hline $\begin{array}{l}\text { Between } \\
\text { Groups }\end{array}$ & 1.352 & 4 & .338 & 3.336 & .038 \\
Within & 1.520 & 15 & .101 & & \\
Groups & 2.872 & 19 & & & \\
Total & & & & \\
\hline
\end{tabular}

* Marked effects are significant at $\mathrm{p}<.05000$

The result conveyed that there is a significant difference on the factors affecting the market price of fish. The significant differences on the factors affecting the market price of fish in the northern part of Surigao Del Sur vary from the differing effects which contribute to the price formulation of the fish in the same region. This means that the market price differential is dependent on the varying factors, which include the quality of fish, fishing location, weather condition, water pollution and price demand. These factors give significant influence on formulating the market price of fish when there is a high purchasing power of consumers, abundant fish population in accessible fishing areas, weather conditions and water pollutions.

\section{Conclusions}

Based on the findings, the following conclusions were made: The quality of fish greatly affects the market price of fish, since most of the consumers preferred to purchase high quality and fresh fish for health and safety reasons. Fishermen prefer to avoid areas which are polluted; instead, they travel to other location where abundant fish can be found. Furthermore, it was found that all the five (5) factors cited in the study have significant contributions on the formulation of the market price of fish in the northern part of Surigao Del Sur.

\section{Recommendations}

The researchers further recommend that keeping the market areas clean and closely monitoring the sanitation would prevent deterioration of quality of fish and would consequently promote quality yield and profits. 


\section{Acknowledgment}

The researchers would like to extend their sincere gratitude to their family, friends and love ones for the unending support and encouragement.

\section{References}

Bruton, M. (1990). Alternative life-history of fishes. Reprinted from Environmental Biology of Fishes, 28(1-4). Springer Science Business and Media. SBN: 978-94-010-7427-8 (Print) 978-94-009-2065-1. [Online] Available: http://link.springer.com/bookseries/5826

Craig, J. F. (2014). Journal of fish biology, 85(4), 987-1296. [Online] Available: http://onlinelibrary.wiley.com/journal/10.1111/(ISSN)1095-8649/issues?year=2014

DA-BFAR. (2004). In turbulent seas: The status of Philippine marine fisheries. Coastal Resource Management Project, Department of Agriculture - Bureau of Fisheries and Aquatic Resources. Cebu City, Philippines, pp. 378

Graddy (2006). Markets the Fulton fish market. Department of Economics. Manor Road Building, Oxfor OX1 3UQ. Journal of Economic Perspective, ISSN 1471-0498.

Green, et. al. (2015). Provenance of Global Seafood, 17(3), 585-595. http://dx.doi.org/10.1111/faf.12129 [Online] Available: http://onlinelibrary.wiley.com/doi/10.1111/faf.12129/suppinfo.

HLPE (2014). Sustainable fisheries and aquaculture for food security and nutrition. A report by the High Level Panel of Experts on Food Security and Nutrition of the Committee on World Food Security, Rome 2014. [Online] Available: http://www.fao.org/3/a-i3844e.pdf

Israel, D.C. (2004). Economics and environment in the fisheries sector. CRMP Document No: 02-CRM/2004. ISBN 971-92753-4-0 In: DA-BFAR, 2004, q.v. pp. 131-137. [Online] Available: http://www.oneocean.org/download/db_files/fshprofl.pdf

Namisi, P. (2005). Social and economic implications of fishery distribution patterns on Lake Victoria, Uganda. LVEMP Socio-economic Research Report 3. NARO-FIRRI, Jinja

Peterson \& Fronc, Karl (2007). Fishing for Consumers: Market-driven factors affecting the sustainability of fish and seafood supply chain. Online ISBN: 9780511542183, Book DOI: http://dx.doi.org/10.1017/CBO9780511542183; [Online] Available: https://scholars.opb.msu.edu/en/publications/fishing-for-consumers-market-driven-factors-aff ecting-the-sustain-4

Savin, et. al (2010). Analysis of factors affecting fish purchasing decisions of the household: Antalya District Case. Journal of Animal and Veterinary Advances, 9(12), 1689-1695

Yamashita (1996). Factors affecting domestic price differentials in theJapanese fisheries and marine products. Department of Economics, Meikai University, IDE- APEC STUDY Center, Working Paper series 95/96-No.3 


\section{Copyright Disclaimer}

Copyright for this article is retained by the author(s), with first publication rights granted to the journal.

This is an open-access article distributed under the terms and conditions of the Creative Commons Attribution license (http://creativecommons.org/licenses/by/3.0/). 